\title{
Changes in cultivar-specificity toward pea can result from transfer of plasmid RP4 and other incompatibility group P1 replicons to Pseudomonas syringae pv. pisi.
}

\author{
Paul J. Moulton, ${ }^{1}$ Alan Vivian, ${ }^{1 *}$ Paul J. Hunter ${ }^{1} \dagger$ and John D. Taylor ${ }^{2}$ \\ 'Department of Biological Sciences, University of the West of England, Frenchay Campus, Coldharbour Lane, \\ Bristol 'BSI6 IQY, UK \\ ${ }^{2}$ Horticulture Research International, Wellesbourne, Warwick CV35 9EF, UK
}

(Received 25 June 1993; revised 21 July 1993; accepted 23 July 1993)

\begin{abstract}
Transfer of RP4 and related replicons belonging to the Escherichia coli incompatibility group P (Pseudomonas aeruginosa IncP1) to races 2 and 6 of $P$. syringae pv. pisi was associated with the creation of two types of transconjugant, one resembling the parental race and the other showing an altered cultivar-specificity towards pea. The latter, irrespective of the parental race, exhibited a novel pattern of interaction with pea that corresponded to race 4; consequently such transconjugants were termed race 4-like. Curing of RP4 did not affect the phenotype, except in relation to the antibiotic resistances specified by RP4. The race 4-like strains were nonfluorescent when cultured on appropriate media (in contrast to the particular isolates of races 2 and 6 from which they were derived), showed an enhanced ability to inherit RP4 subsequently (at frequencies up to $10^{-1}$ per recipient) and differed from their parental race in their pattern of plasmid profile. The plasmid profiles were similar for all race 4-like strains irrespective of origin. There was no evidence that RP4 had recombined with DNA in the recipient and probing failed to detect the retention of any part of RP4 in cured strains. The inheritance of the related cosmid vector, pLAFR3, had similar effects in races 2 and 6 . This observation is important since this vector has been widely used to clone avirulence genes in plant pathogenic bacteria. Transfer of the IncW plasmids S-a and R388 did not cause any changes in the fluorescence or cultivar-specificity of races 2 or 6 . The novel avirulence expressed by the race 4-like variants derived from races 2 and 6 provides evidence for the presence in races 2 and 6 of an inhibitor/suppressor gene, which modulates the expression of the race 4-like avirulence gene.
\end{abstract}

\section{Introduction}

Plant pathogenic bacteria often exhibit considerable specificity in their interactions with potential host plants. In pathovars of Pseudomonas syringae, this specificity appears to be based upon matching genes for recognition in the host and pathogen. The response of the host to invasion by the pathogen is determined by avirulence (avr) genes in the pathogen and matched resistance (R) genes in the host. When a race of the pathogen carries an avr gene that is matched by the presence of an $\mathrm{R}$ gene in the host the interaction which occurs results in the induction of the host defence mechanism, often seen as a hypersensitive reaction. In the absence of the matching avr and $\mathrm{R}$ genes disease is the outcome (Keen, 1990).

* Author for correspondence. Tel. +44272 763834; fax +44272 763871; e-mail a-vivian@uk.ac.uwe.pat.

$\uparrow$ Present address: Horticulture Research International, Wellesbourne, Warwick, CV35 9EF, UK.
The cloning of avirulence genes in P. syringae pv. pisi and other pathovars (Vivian, 1992) has been based on the use of gene libraries constructed in vectors, such as pLAFR1 (Friedman et al., 1982) and its derivatives, based upon the Escherichia coli incompatibility group $\mathrm{P}$ (IncP) plasmid RK2 (Ingram et al., 1973). This strategy has enabled the transfer of library-cloned DNA between E. coli and $P$. syringae.

To account for the specificity observed in the races of $P$. syringae pv. pisi and pea (Pisum sativum) a gene-forgene model has been proposed (Taylor et al., 1989; Bavage et al., 1991). Of the five avr genes postulated to occur, two (A2 and A3 in the scheme of Taylor et al., 1989) have been cloned (Vivian et al., 1989; Bavage et al., 1991). The A2 gene has been shown to interact with a single R2 gene in P. sativum (Vivian et al., 1989) and also with the RPM1 gene in Arabidopsis thaliana (Dangl et al., 1992).

Race 6 was first recognized recently as a variant derived from the race 3 strain $870 \mathrm{~A}$, although an isolate 
Table 1. Bacterial strains and plasmids

\begin{tabular}{|c|c|c|}
\hline $\begin{array}{l}\text { Strain or } \\
\text { plasmid }\end{array}$ & Relevant properties & Reference/source \\
\hline \multicolumn{3}{|c|}{ P. syringae pv. pisi } \\
\hline 203 & $\begin{array}{l}\text { Race 2, wild-type; fluorescent; } \\
\text { derivatives prefixed PN }\end{array}$ & Taylor et al. (1989) \\
\hline PN2 & Rif- $r$ (spontaneous mutant) & 203 \\
\hline PN6 & $\begin{array}{l}\text { PN2(pLAFR3); non-fluorescent; } \\
\text { behaves as race } 4 \text {-like }\end{array}$ & This paper \\
\hline PN7 & $\begin{array}{l}\text { PN2(RP4); fluorescent; behaves } \\
\text { as race } 2\end{array}$ & This paper \\
\hline PN8 & $\begin{array}{l}\text { PN6 cured of pLAFR3; non-fluorescent; } \\
\text { behaves as race 4-like }\end{array}$ & This paper \\
\hline PN9 & $\begin{array}{l}\text { PN7 cured of RP4; fluorescent; } \\
\text { behaves as race } 2\end{array}$ & This paper \\
\hline 1704B & $\begin{array}{l}\text { Race } 6 \text {, wild-type; fluorescent; } \\
\text { derivatives prefixed PT }\end{array}$ & Taylor et al. (1989) \\
\hline PT2 & Rif-r (spontaneous mutant) & 1704B \\
\hline PT3 & $\begin{array}{l}\text { PT2(RP4); fluorescent; behaves } \\
\text { as race } 6\end{array}$ & This paper \\
\hline PT4 & $\begin{array}{l}\text { PT2(RP4); non-fluorescent; behaves } \\
\text { as race 4-like }\end{array}$ & This paper \\
\hline PT9 & $\begin{array}{l}\text { PT3 cured of RP4; fluorescent; } \\
\text { behaves as race } 6\end{array}$ & This paper \\
\hline PT10 & $\begin{array}{l}\text { PT } 4 \text { cured of RP4; non-fluorescent; } \\
\text { behaves as race } 4 \text {-like }\end{array}$ & This paper \\
\hline \multicolumn{3}{|c|}{ Escherichia coli } \\
\hline J5-3 & $\mathrm{Pro}^{-}, \mathrm{Met}^{-}$(host to RP4) & Clowes \& Hayes (1968) \\
\hline 803 & recA, Met $^{-}$(host, pLAFR 3 and clones) & Murray et al. (1977) \\
\hline J53-1 & Pro $^{-}$, Met $^{-}, \mathrm{Nal}^{r}, \mathrm{Lac}^{+}$(host, S-a) & Clowes \& Hayes (1968) \\
\hline J62-1 & $\mathrm{Pro}^{-}, \mathrm{His}^{-}, \mathrm{Trp}^{-}, \mathrm{Lac}^{-}, \mathrm{Nal}^{-}$(host, R388) & Clowes \& Hayes (1968) \\
\hline $39 \mathrm{R} 861$ & $\begin{array}{l}\text { Host to four plasmids used as size } \\
\text { markers }(98,42,23 \cdot 9,4 \cdot 6 \mathrm{MDa})\end{array}$ & Threlfall et al. (1986) \\
\hline \multicolumn{3}{|l|}{ Plasmid } \\
\hline pLAFR3 & $\mathrm{Tra}^{-}, \mathrm{Mob}^{+}, \mathrm{Tc}^{\mathrm{r}}, \mathrm{RK} 2$ replicon & Staskawicz et al. (1987) \\
\hline pRK2013 & $\mathrm{Tra}^{+}, \mathrm{Km}^{\mathrm{r}}$, ColE1 replicon & Figurski \& Helinski (1979) \\
\hline RP4 & $\mathrm{Ap}^{\mathrm{r}}, \mathrm{Km}^{\mathrm{r}}, \mathrm{Tc}^{\mathrm{r}} ; \mathrm{IncP}$ & Datta et al. (1971) \\
\hline R388 & $\mathrm{Su}^{\mathrm{r}}, \mathrm{Tp}^{\mathrm{r}} ; \mathrm{IncW}$ & Datta \& Hedges (1972) \\
\hline S-a & $\mathrm{Cm}^{\mathrm{r}}, \mathrm{Km}^{\mathrm{r}}, \mathrm{Sm}^{\mathrm{r}}, \mathrm{Su}^{\mathrm{r}} ; \mathrm{IncW}$ & Watanabe et al. (1968) \\
\hline
\end{tabular}

obtained from Hungary in 1956 was subsequently shown to correspond to this race. Race 6 is unique in its ability to cause disease in all cultivars of pea tested (Taylor et al., 1989). This led to the conclusion that it did not express any avr genes and therefore probably lacked all the postulated avr genes (A1-A5). It was as a result of attempting to use this race as a recipient of cloned DNA from other races of $P$. syringae pv. pisi that we became aware of the phenomenon of race change associated with plasmid acquisition.

This paper describes the behaviour, in $P$. syringae pv. pisi, of plasmid RP4 (Datta et al., 1971), which is similar or identical to plasmid RK2 (Burkardt et al., 1979). The $E$. coli IncP group corresponds to the group designated IncP1 in P. aeruginosa (Jacoby, 1977); the latter designation will be used in this paper. Introduction of RP4 and other IncP1 replicons into strains of $P$. syringae pv. pisi was associated with complex changes of phenotype including host range and loss of the ability to produce fluorescent pigment.

\section{Methods}

Culture of bacterial strains. The bacteria and plasmids used are listed in Table 1. Rifampicin-resistant mutants of the wild-type strains were obtained by plating aliquots $(0.1 \mathrm{ml})$ of an overnight nutrient broth culture on King's medium B containing rifampicin $\left(100 \mu \mathrm{g} \mathrm{ml}^{-1}\right)$. Strains of Escherichia coli and P. syringae pv. pisi were cultured as described by Bavage et al. (1991). Fluorescent pigment production was observed after growth $\left(25^{\circ} \mathrm{C}, 2 \mathrm{~d}\right)$ of strains of $P$. syringae pv. pisi on King's medium B (King et al., 1954). Plasmid transfer between bacteria was either by filter-matings as described by Malik et al. (1987) or by replica-plate matings as described by Vivian et al. (1989), omitting the helper plasmid where transfer of a conjugative plasmid was being sought.

DNA manipulation techniques. These were based on the methods of Sambrook et al. (1989), modified by Bavage et al. (1991). Plasmid DNA for digestion with restriction endonucleases was isolated by the method of Bavage et al. (1991). Whole plasmids in P. syringae pv. pisi and $E$. coli were visualized by the following method. Cells were harvested from broth cultures $(0.35 \mathrm{ml}$ for $P$. syringae; $0.175 \mathrm{ml}$ for $E$. coli) in $1.5 \mathrm{ml}$ Eppendorf tubes in a microfuge and resuspended in $20 \mu \mathrm{l} \mathrm{TE}$ (10 mM Trizma base, $\mathrm{pH} 8 \cdot 5 ; 1 \mathrm{~mm}-\mathrm{Na}_{2}$ EDTA) and $15 \mu \mathrm{l}$ of an alkaline SDS solution $(0.2 \mathrm{M}-\mathrm{NaOH} ; 0.2 \%$ SDS $)$, mixing the contents thoroughly. The tubes were left to stand at room temperature ( $5 \mathrm{~min}$ ) 


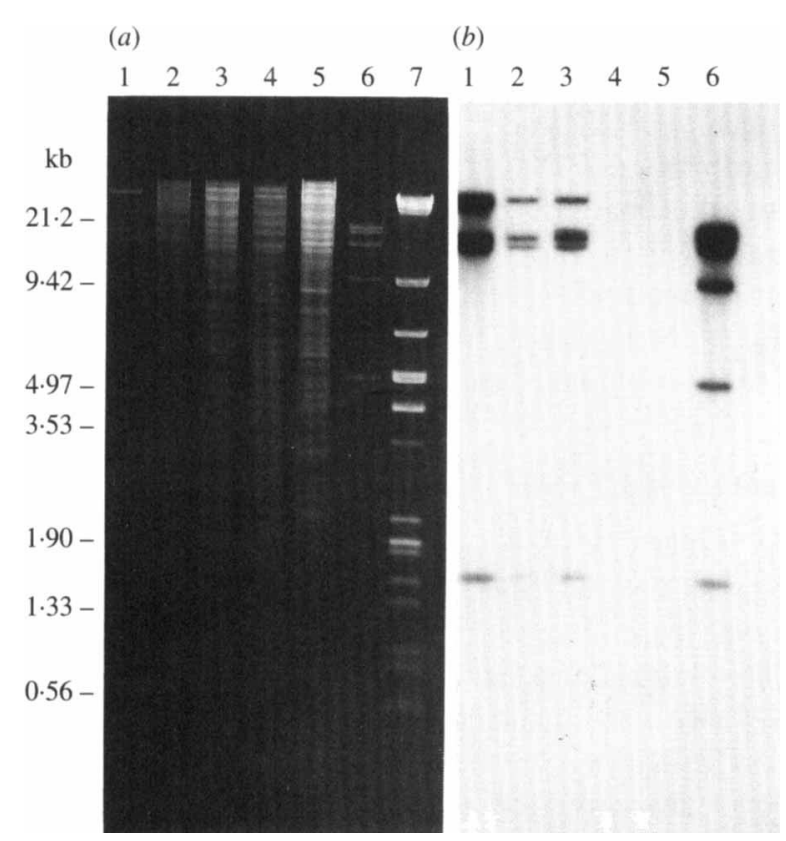

Fig. 1. Total DNA from race 6 and transconjugant derivatives digested and probed with RP4. Total DNA was isolated and digested with KpnI as described in Methods. ( $a$ ) The resulting fragments were separated by electrophoresis on a $0.5 \%$ agarose gel run at $40 \mathrm{~V} \mathrm{~cm}^{-1}$ for $18 \mathrm{~h}$. The strains prefixed PT were derived from race 6. Tracks: 1, plasmid RP4; 2, PT3 (race 6-like harbouring RP4) 3, PT4 (race 4-like harbouring RP4) 4, PT9 (as PT3 but cured of RP4) 5, PT10 (as PT4 but cured of RP4) 6, plasmid RP4 ApaI/KpnI digest; 7, lambda standard HindIII/ EcoRI, HindIII. (b) Autoradiograph obtained after blotting $(a)$ and probing with ${ }^{32} \mathrm{P}$-labelled RP4 at high stringency.

before addition of $40 \mu \mathrm{l}$ of phenol/chloroform/isoamyl alcohol $(25: 24: 1$, by vol.). An emulsion was formed by repeatedly flicking the end of each tube. The two phases were separated (microfuge, $3 \mathrm{~min}$ ), $0.5 \mu \mathrm{l}$ of loading dye $(0.25 \%$ xylene cyanol, $0.25 \%$ bromophenol blue, $1.5 \%(\mathrm{w} / \mathrm{v})$ Ficoll 400$)$ was added to the upper phase which was then immediately loaded in wells formed by a comb ( 20 positions $1 \times 6.4 \times$ $6 \mathrm{~mm})$ in a $0.6 \%$ agarose gel $(200 \times 250 \times 8 \mathrm{~mm})$ in TBE $(90 \mathrm{mM}$-Trizma base, $90 \mathrm{~mm}$-boric acid, $2.5 \mathrm{~mm}-\mathrm{Na}_{2}$ EDTA; $\mathrm{pH} \mathrm{8.0)}$. After standing for $5 \mathrm{~min}$, electrophoresis was performed in a horizontal gel apparatus (Bio-Rad) at $75 \mathrm{~V}$ for $30 \mathrm{~min}$. Then, without switching off the apparatus, the voltage was increased to $200 \mathrm{~V}$ for a further $4 \mathrm{~h}$.

Gels were stained by submersion $(15 \mathrm{~min})$ in a solution of ethidium bromide $\left(10 \mu \mathrm{g} \mathrm{ml}^{-1}\right.$ in TE), placed on a transilluminator (model TM40, UV Products Inc.) and photographed using a C15 Land camera with 665 film (Polaroid). The plasmids in E. coli strain 39R861 used as size markers (Table 1) were converted from sizes in megadaltons to kilobase pairs using the conversion factor $1 \mathrm{MDa}=1.575 \mathrm{~kb}$ (Sambrook et al., 1989).

Plasmid curing. This was based on a technique described as 'cold curing' by Malik (1985), which relies upon the ability of phytopathogenic pseudomonads to grow at low temperature (about $5{ }^{\circ} \mathrm{C}$ ). Under these conditions plasmids such as RP4, which is stably maintained at normal growth temperatures in E. coli, is lost at increased frequency. Nutrient broth (Oxoid; $10 \mathrm{ml}$ ) was inoculated with $0.1 \mathrm{ml}$ overnight broth culture and incubated at $4{ }^{\circ} \mathrm{C}$ with shaking for 5-7 d. Appropriate dilutions were spread on nutrient agar (Oxoid) plates and incubated $\left(25^{\circ} \mathrm{C}, 2 \mathrm{~d}\right)$ to give single colonies. These were replica-plated to identify those colonies which were sensitive to tetracycline, indicating presumptive loss of RP4. Loss was confirmed by plasmid DNA isolation using the method of Holmes \& Quigley (1981).

Plasmid stability. The measurement of stability of RP4 and pLAFR3 used the following method. Antibiotic-free broth cultures $\left(18 \mathrm{~h}, 25^{\circ} \mathrm{C}\right)$ were inoculated with single colonies taken from a selective plate culture. Appropriate dilutions to produce single colonies were cultured $\left(2 \mathrm{~d}, 25^{\circ} \mathrm{C}\right)$ on nutrient agar (Oxoid) plates. Loss of RP4/pLAFR3 was determined by replica-plating to tetracycline-containing plates.

Plant inoculation. Plants for testing were grown in Levington compost in plastic trays, containing 40 cells each of $50 \mathrm{~cm}^{3}$, maintained in glasshouses at temperatures of $18-20^{\circ} \mathrm{C}$. Approximately $14 \mathrm{~d}$ after sowing the plants were inoculated by scraping the bacterial inoculum from the surface of culture plates with the tip of a sterile entomological mounting pin and stabbing vertically into the main stem of the plant at the junction of the stem and stipules at the two youngest nodes (two inoculations per plant, per isolate). Plant reactions were recorded $7 \mathrm{~d}$ after inoculation. A susceptible response was characterized by an area of water-soaking around the site of inoculation while a hypersensitive response was characterized by a necrotic area around the site of inoculation (Bavage et al., 1991)

\section{Results}

\section{Conjugation of plasmid RP4 from Escherichia coli to P. syringae pv. pisi}

Filter-matings were performed between Escherichia coli strain J5-3(RP4) and rifampicin-resistant derivatives of the $P$. syringae pv. pisi wild-type races 2 and 6 . The frequencies of inheritance of RP4 differed between the two races: for PN2 (race 2) the frequency of tetracyclineresistant transconjugants per recipient was $4.7 \pm 1.8 \times$ $10^{-3}$ (average of five matings) and for PT2 (race 6) it was $7 \cdot 8 \pm 4 \cdot 7 \times 10^{-6}$ (average of four matings).

Six tetracycline-resistant transconjugants were isolated from one of the matings between $E$. coli carrying RP4 and the fluorescent race 6 strain (PT2). These transconjugants were of two types with respect to fluorescent pigment production, readily distinguished on King's medium B. One (designated PT3) retained the ability to produce fluorescent pigment, whereas the remaining five were all non-fluorescent. Since all five transconjugants showed a similar phenotype one strain (designated PT4) was chosen from this group for comparison with strain PT3.

Similarly, conjugation of either RP4 or pLAFR3 into the race 2 strain PN2 generated both fluorescent and non-fluorescent transconjugants. Thus, a sample of 20 transconjugants from a mating between $E$. coli J5-3(RP4) and PN2 were tested for fluorescence. Thirteen (including the strain designated PN7) were fluorescent and seven were non-fluorescent. An example of a nonfluorescent transconjugant was strain PN6 carrying pLAFR3, obtained in a separate mating experiment.

Cured derivatives of each of the transconjugants PT3, PT4, PN6 and PN7 were isolated on the basis of loss of antibiotic resistance: each cured derivative (strains PT9, PT10, PN8 and PN9, respectively) retained the fluor- 
Table 2. Cultivar specificity of RP4 transconjugants of race 2 and race 6 and their cured derivatives

Stem-inoculation of pea seedlings was as described in Methods. Each strain was inoculated in ten plants of each cultivar, except PT9 and PT10 (three plants per cultivar) and PN6-9 (five plants per cultivar). + , Compatible (disease); - , incompatible (hypersensitive response).

\begin{tabular}{lcccccccc}
\hline \hline & \multicolumn{7}{c}{ Cultivar* } \\
\cline { 2 - 9 } Resistance & KW & EO & B & HGS & P & ST & V & F \\
genes $\dagger \ldots$ & 0 & 2 & 3 & $? 1,4$ & $? 1,3$ & $? 1,2$, & 1,2, & $? 1,2$, \\
& & & & & 4 & $4, ? 5$ & 3,5 & 3,4 \\
Strain no. & & & & & & & & \\
\hline 1704B & + & + & + & + & + & + & + & + \\
PT2 & + & + & + & + & + & + & + & + \\
PT3 & + & + & + & + & + & + & + & + \\
PT4 & + & + & + & - & - & - & + & - \\
PT9 & + & + & + & + & + & + & + & + \\
PT10 & + & + & + & - & - & - & + & - \\
203 & + & - & + & + & + & - & - & - \\
PN2 & + & - & + & + & + & - & - & - \\
PN6 & + & + & + & - & - & - & + & - \\
PN7 & + & - & + & + & + & - & - & - \\
PN8 $\ddagger$ & + & + & + & - & - & - & + & - \\
PN9 & + & - & + & + & + & - & - & - \\
\hline \hline
\end{tabular}

* KW, Kelvedon Wonder; EO, Early Onward; B, Belinda; HGS, Hursts Greenshaft; P, Partridge; ST, Sleaford Triumph; V, Vinco; F, Fortune.

$\dagger$ Postulated resistance genes in each cultivar (Bavage et al., 1991); ?, no evidence for the presence or absence of the $\mathrm{R}$ gene indicated. $\ddagger$ Martus (R2) used instead of Early Onward.

escence phenotype of its progenitor. To investigate the possibility that part of RP4 had recombined with some other replicon in the recipient, total DNA blots of PT3, PT4, PT9 and PT10 were probed with radioactivelylabelled-RP4 (Fig. 1). The results indicate that the fragments obtained after digestion of RP4 with $K p n I$ were present and unchanged in size in PT3 and PT4, but were absent from the cured derivatives.

Subsequent conjugation of RP4 from E. coli into strains PT9 and PT10 showed that the inheritance frequency of RP4, based on the inheritance of tetracycline resistance differed considerably between the two strains. The frequency for PT9 was $3 \cdot 3 \pm 2.0 \times 10^{-7}$ (average of eight matings), similar to that for race 6 , while the frequency for PT10 was $6.8 \pm 1.8 \times 10^{-1}$ (average of four matings). Thus a further feature of the race 4-like phenotype was an enhanced ability to receive RP4 and other IncP1 replicons (data not shown).

\section{Plant tests}

All the cured derivative strains designated above were tested on the pea differential series, together with their RP4- or pLAFR3-carrying progenitors and appropriate control strains. The results (Table 2) show that strain PT3, its cured derivative, PT9 and the race 6 strain PT2 were compatible with all pea cultivars. The strains PN7 and PN9 showed the same cultivar-specificity as their progenitor, PN2 (race 2). The non-fluorescent derivatives of both race 6 (PT4 and PT10) and race 2 (PN6 and PN8) showed a pattern of interaction with pea that corresponded to that of race 4 (Taylor et al., 1989). Consequently these strains will be referred to as 'race 4like' to distinguish them from naturally-occuring isolates of race 4 obtained from pea.

\section{Stability of RP4 and pLAFR3 in P. syringae pv. pisi}

The stability of the plasmids introduced into PT3, PT4, PN6 and PN7 was tested. The results (Table 3) show that in each case, except PT3, the introduced plasmid was relatively stable and could be conjugated to $E$. coli strain $5 \mathrm{~K}-1$ (with the helper plasmid pRK2013 in the case of pLAFR3). The exception, PT3, which retained a race 6 phenotype, exhibited an inability to retain RP4 or to produce transconjugants in E. coli.

\section{Plasmid profiles}

Native plasmids were separated from strains PT9 and PT10 (which had been cured of RP4) and from PN8 and PN9 (similarly cured derivatives from race 2) and sized by comparison with appropriate standards (Fig. 2). The race 6-like derivative (PT9) retained the same plasmid profile as PT2 (two plasmids: approximately 117 and $64 \mathrm{~kb}$ ), while the race 4-like derivative (PT10) showed an altered plasmid profile (two plasmids: approximately 60 and $56 \mathrm{~kb}$ ). The race 2-like derivative (PN9) retained the same plasmid profile as PN2 (two plasmids: approximately 100 and $64 \mathrm{~kb}$ ), while the race 4-like derivative (PN8) showed an altered plasmid profile (two plasmids: approximately 60 and $56 \mathrm{~kb}$ ), which was apparently the same as that shown by PT10.

\section{Inheritance of IncW plasmids}

To investigate whether the changes observed could be brought about by the inheritance of broad-host-range plasmids of a different incompatibility group, the IncW plasmids R388 and S-a were conjugated with race 2 and R388 with race 6 . The frequency with which PN2 and PT2 inherited the two plasmids differed considerably from the frequency of inheritance of RP4. The frequencies for race 2 were: PN2 $\times$ J53-1(S-a) $5 \cdot 0 \pm 2 \cdot 5 \times$ $10^{-1}$ (average of three matings) and PN $2 \times \mathrm{J} 62-1$ (R388) $1.6 \pm 0.4 \times 10^{-2}$ (average of four matings). The frequency for race 6 was: PT2 $\times$ J62-1(R388) $3.0 \pm 2.3 \times 10^{-4}$ (average of five matings).

Approximately 20 transconjugants of each of the three matings were examined and all retained the fluorescent 
Tale 3. Stability of tetracycline resistance in transconjugants of race 2 and race 6

Stability was determined as described in Methods.

\begin{tabular}{cccc}
\hline \hline Strain & Race & $\begin{array}{c}\text { Percentage of cells } \\
\text { retaining Tc }\end{array}$ & $\begin{array}{c}\text { Mating with 5K-1* } \\
\text { (transconjugants } \\
\text { per recipient) }\end{array}$ \\
\hline PT4 & 4-like & $98 \cdot 8 \pm 0 \cdot 3(n 16)$ & $7 \cdot 6 \pm 0.95 \times 10^{-1}(n 3)$ \\
PT3 & 6-like & $8 \cdot 0 \pm 0 \cdot 7(n 14)$ & $0(n 3)$ \\
PN6 & 4-like & $81 \cdot 0 \pm 3 \cdot 8(n 11)$ & $6 \cdot 7 \pm 0 \cdot 81 \times 10^{-5}(n 3)$ \\
PN7 & 2-like & $94 \cdot 2 \pm 1 \cdot 7(n$ 7) & $1 \cdot 1 \pm 0.32 \times 10^{-3}(n 3)$ \\
\hline \hline
\end{tabular}

* Plasmid pRK2013 was present in the mating between 5K-1 and PN6.

Table 4. Cultivar-specificity of IncW plasmid transconjugants of $P$. syringae pv. pisi races 2 and 6

Stem-inoculation of pea was as described in Methods. Three independent transconjugants of race 2 carrying either R388 or S-a and race 6 carrying R388 were inoculated on ten plants of each cultivar. Responses were recorded as: + , compatible (disease); - , incompatible (hypersensitive response).

\begin{tabular}{lcccccccc}
\hline \hline & \multicolumn{10}{c}{ Cultivar* } \\
\cline { 2 - 9 } Resistance & KW & EO & B & HGS & P & ST & V & F \\
genes $\dagger . .$. & 0 & 2 & 3 & $? 1,4$ & $? 1,3$ & $? 1,2$, & 1,2, & $? 1,2$, \\
Strain no. & & & & & 4 & $4, ? 5$ & 3,5 & 3,4 \\
\hline PN2 & + & - & + & + & + & - & - & - \\
PN2(S-a) & + & - & + & + & + & - & - & - \\
PN2(R388) & + & - & + & + & + & - & - & - \\
PT2 & + & + & + & + & + & + & + & + \\
PT2(R388) & + & + & + & + & + & + & + & + \\
\hline \hline
\end{tabular}

* KW, Kelvedon Wonder; M, Martus; B, Belinda; HGS, Hursts Greenshaft; P, Partridge; ST, Sleaford Triumph; V, Vinco; F, Fortune. + Postulated resistance genes in each cultivar (Bavage et al., 1991);

?, no evidence for the presence or absence of the $\mathbf{R}$ gene indicated.

phenotype of the parental recipient race. Of these, three transconjugants from each mating were tested on the pea differential series (Table 4). All transconjugants retained the cultivar-specificity of their progenitor race.

\section{Discussion}

Matings between $E$. coli $\mathrm{RP} 4$ and $P$. syringae pv. pisi race 2 and race 6 gave rise to two types of transconjugant. In each case plasmid acquisition was associated with what appears to be the simple inheritance of RP4 in an otherwise unchanged race 2 or 6 host, or involved extensive deletion of plasmid DNA accompanied by a complex set of phenotypic changes to create a transconjugant exhibiting a race 4 phenotype on pea cultivars. It remains unclear what determines the type of transconjugant that arises.

An alternative explanation envisages that wild-type race 2 and race 6 isolates harbour a small proportion of

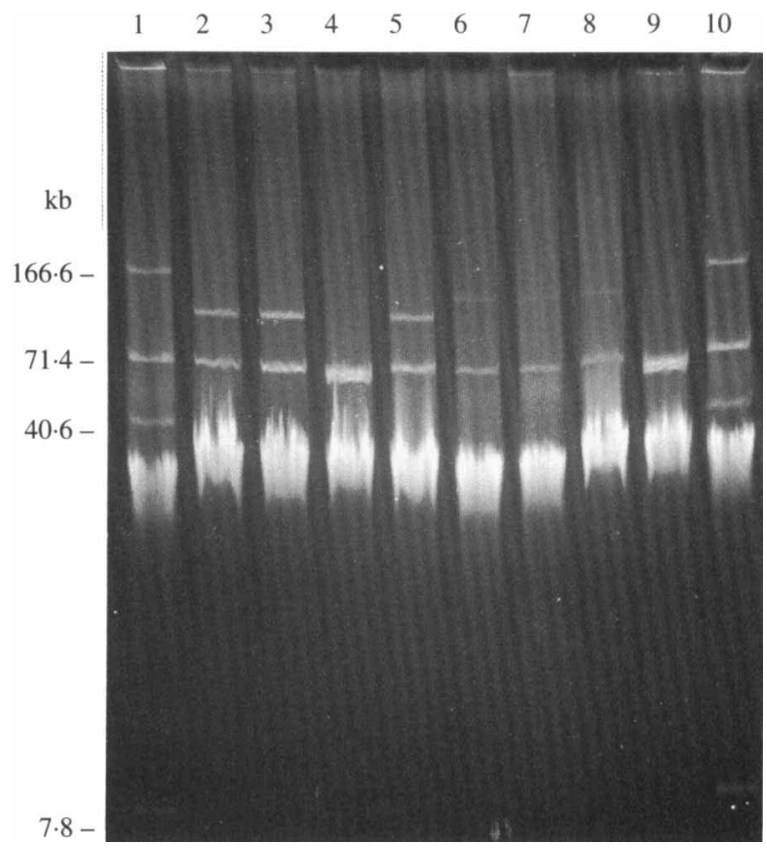

Fig. 2. Plasmid DNA from races 2 and 6 and transconjugant derivatives cured of RP4 or pLAFR3. Plasmid DNA was isolated and separated by electrophoresis on a $0.6 \%$ agarose gel as described in Methods. The strains prefixed PT were derived from race 6 and those prefixed PN were from race 2. Tracks: 1 and 10, E. coli 39R861 size standards; 2, 203 (race 2 wild-type); 3, PN2 (Rif ); 4, PN8 (race 4-like cured of pLAFR3); 5, PN9 (race 2-like cured of RP4); 6, 1704B (race 6 wild-type); 7, PT2 (Rif'); 8, PT9 (race 6-like cured of RP4); 9, PT10 (race 4-like cured of RP4). P. syringae pv. pisi plasmids were sized by comparison with the four plasmids from strain $39 \mathrm{R} 861$ whose sizes are $154,66 \cdot 2,37.6$ and $7.2 \mathrm{~kb}$ (Threlfall et al., 1986).

race 4-like variants, which pre-exist prior to the acquisition of RP4, but which appear disproportionately amongst the transconjugants because of their enhanced ability to inherit and retain RP4. The differences in frequencies of RP4 inheritance between race 4-like (approximately $10^{-1}$ ) and race 6 (approximately $10^{-7}$ ) suggest that there is at best a 1 in $10^{6}$ chance of observing a variant colony on plating out dilutions of race 6 ; the chance in the case of race 2 would appear to be 1 in 100 , but screening for spontaneous variants among over 4000 single colonies failed to detect any showing loss of fluorescence.

Curing of RP4 from each type of transconjugant showed that the novel race 4-like phenotype is not due to the presence of RP4, although it is possible that some plasmid-borne function is associated with the events responsible for the appearance of the race 4-like variants. The race 4-like strains, irrespective of their progenitor race, showed identical phenotypes with respect to fluorescent pigment production, plasmid profiles, plasmid recipient ability and cultivar-specificity in pea. Since race 2 and race 6 differ in their plasmid content, it 
seems likely that it is the retention of specific plasmid DNA sequences accompanied by loss of variable amounts of other plasmid sequences, rather than the deletion of specific sequences, that is involved. The total loss of DNA would appear to be approximately $48 \mathrm{~kb}$ from race 2 and $65 \mathrm{~kb}$ from race 6 .

The results obtained after conjugation of the IncW plasmids, R388 and S-a, into races of $P$. syringae pv. pisi indicated that the generation of race 4-like strains was only associated with the entry of plasmids of certain incompatibility groups and may be IncPl-specific. Changes in the frequencies of inheritance of plasmids were also reported in the cherry pathogen, $P$. syringae pv. morsprunorum, although the variants, designated $\mathrm{Ipm}^{-}$(interference with plasmid maintenance), were not tested for plant reactions. Ipm $^{-}$strains showed an enhanced ability, compared with their progenitors, to inherit plasmids from incompatibility groups IncC, IncP and IncW (Vivian et al., 1983), suggesting that they were different in nature to the variants described here.

Perhaps the most significant observation is that the cured race 4-like derivatives from race 6 exhibit a novel avirulence specificity, which was not expressed in the parental race 6 . This does not appear to be due to the presence of an avirulence gene on RP4, since both IncP1 replicons (RP4 and pLAFR3) generate similar transconjugants and the curing of the acquired plasmid does not cause a loss of the novel avirulence. It implies that the A4-like avirulence gene must have been present in race 6 (and also in race 2 ), but in both cases its expression was inhibited or suppressed. This inhibition/suppression is lost either by gene deletion or by some rearrangement of plasmid DNA, perhaps involving site-specific transposition resulting in gene inactivation.

Although this appears to be the first evidence for the existence of an inhibitor/suppressor gene controlling expression of an avr gene in bacteria, such inhibitor genes are well documented in plant-fungal interactions. In the flax rust fungus, Melampsora lini, an apparent exception to the 'gene-for-gene rule' on flax (Linum usitatissimum) cultivar Williston Brown could best be explained in terms of two genes in the pathogen interacting to determine compatibility. Thus, Lawrence et al. (1981) showed that the resistance gene $M$ was matched by an avirulence gene pair $(A / a)$ and an inhibitor gene pair $(I / i)$ and that the expression of avirulence was only possible when the pathogen carried the double recessive $i i$ genotype. These authors also concluded that a similar $A / I$ gene pair matched a series of resistance alleles at gene $L$. Other examples of inhibitors of specific $A$ genes include wheat leaf rust (Puccinia recondita f. sp. tritici) and the Lr3a resistance in wheat (Samborski \& Dyck, 1968); downy mildew of lettuce (Bremia lactucae) and resistances $R 4$ (Michelmore et al., 1984), $R 1$ and $R 5 / R 8$ (Norwood \& Crute, 1984) in lettuce (Lactuca sativa L.); and bean rust (Uromyces phaseoli var. typica) in bean (Phaseolus vulgaris) (Christ $\&$ Groth, $1982 a, b$ ). In each case there was evidence for the operation of an epistatic inhibitor gene modulating the expression of a dominant avirulence gene. As Crute (1985) has pointed out these examples may be indicative of an additional tier of genetic control superimposed on the generally recognized gene-for-gene pattern. The extension of such dual systems to bacterial phytopathogens provides further evidence for their generality. As such, the significance of genes that in effect extend host range cannot be overstated in relation to the breakdown of field resistance due to the appearance of novel pathogen races.

The ability to produce fluorescent pigment would also appear to involve genes that are plasmid-borne and deleted or lost. In $P$. syringae pv. syringae genetic analysis of the production of an extracellular, watersoluble, yellow-green fluorescent pigment indicated that at least four genes or gene clusters were involved (Loper et al., 1984). There was no evidence to indicate whether any of these genes was plasmid-borne. A similar type of pigment from a different isolate of $P$. syringae pv. syringae was shown to be a pyoverdin siderophore (Cody \& Gross, 1987).

Finally, the widespread use of cosmid cloning vectors based on plasmids of the IncPl group may have consequences for the study of those avirulence genes that are plasmid-borne in plant pathogenic bacteria. Several groups have used pLAFR3 and similar derivatives of RK2 to construct gene libraries for re-introduction into pathovars of $P$. syringae (Staskawicz et al., 1984, 1987; Dong et al., 1991; Whalen et al., 1988, 1991). The results presented here suggest that it is essential that investigators study the effects of cosmid introduction per se into strains and whether a substantial proportion of single transconjugants show any evidence of race change of the type observed in $P$. syringae pv. pisi.

We are indebted to Adrian Bavage, Ian Crute, Luis Mur and Julie Orvis for helpful discussion. This work was supported in part by a SERC-funded studentship to P.J.M., and also with support from AFRC and the EC BRIDGE programme (Contract BIOT C T90*0168, UK(JR) to A.V. This work was carried out under MAFF licence number PHF 678/81 (91) issued under the Plant Health (Great Britain) Order 1987.

\section{References}

Bavage, A. D., Vivian, A., Atherton, G. T., Taylor, J. D. \& Malik, A. N. (1991). Molecular genetics of Pseudomonas syringae pathovar pisi: plasmid involvement in cultivar-specific incompatibility. Journal of General Microbiology 137, 2231-2239.

Burkardt, H.-J., Riess, G. \& Puhler, A. (1979). Relationship of group P1 plasmids revealed by heteroduplex experiments: RP1, RP4, R68 and RK2 are identical. Journal of General Microbiology 114, 341-348. 
Christ, B. J. \& GROTH, J. V. (1982a). Inheritance of virulence to three bean cultivars in three isolates of the bean rust pathogen. Phytopathology 72, 767-770.

Christ, B. J. \& Groth, J. V. (1982 b). Inheritance of resistance to three cultivars of beans to the bean rust pathogen and the interaction of virulence and resistance genes. Phytopathology 72, 771-773.

Clowes, R. C. \& HAYES, W. (1968). Experiments in Microbial Genetics. Oxford \& Edinburgh: Blackwell Scientific Publications.

CoDY, Y. S. \& Gross, D. C. (1987). Characterization of pyoverdin ${ }_{\mathrm{pss}}$, the fluorescent siderophore produced by Pseudomonas syringae pv. syringae. Applied and Environmental Microbiology 53, 928-934.

Crute, I. R. (1985). The genetic bases of relationships between microbial parasites and their hosts. In Mechanisms of Resistance to Plant Disease pp. 80-141. Edited by R. S. S. Fraser. Dordrecht: Martinus Nijhoff \& W. Junk.

Dangl, J. L., Ritter, C., Gibbon, M. J., Mur, L. A. J., Wood, J. R., Goss, S., Mansfield, J., Taylor, J. D. \& Vivian, A. (1992). Functional homologs of the Arabidopsis RPMI disease resistance gene in bean and pea. Plant Cell 4, 1359-1369.

Datta, N. \& Hedges, R. W. (1972). Trimethoprim resistance conferred by $\mathrm{W}$ plasmids in Enterobacteriaceae. Journal of General Microbiology 72, 349-356.

Datta, N., Hedges, R. W., Shaw, E. J., Sykes, R. B. \& Richmond. M. H. (1971). Properties of an $\mathbf{R}$ factor from Pseudomonas aeruginosa. Journal of Bacteriology 108, 1244-1249.

Dong, X., Mindrinos, M., Davis, K. R. \& Ausubel, F. M. (1991). Induction of Arabidopsis defense genes by virulent and avirulent Pseudomonas syringae strains and by a cloned avirulence gene. Plant Cell 3, 61-72.

FigURSKI, D. H. \& Helinski, D. R. (1979). Replication of an origincontaining derivative of plasmid RK2 dependent on a plasmid function provided in trans. Proceedings of the National Academy of Sciences of the United States of America 76, 1648-1652.

Friedman, A. M., Long, S. R., Brown, S. E., Buikema, W. J. \& Ausubel, F. M. (1982). Construction of a broad host range cosmid cloning vector and its use in the genetic analysis of Rhizobium mutants. Gene 18, 289-296.

Holmes, D. S. \& Quigley, M. (1981). A rapid boiling method for the preparation of bacterial plasmids. Analytical Biochemistry 114 . 193-197.

IngRam, L. C., Richmond, M. H. \& Sykes, R. B. (1973). Molecular characterization of the $\mathrm{R}$ factors implicated in the carbenicillin resistance of a sequence of Pseudomonas aeruginosa strains isolated from burns. Antimicrobial Agents and Chemotherapy 3, 279-288.

JACOBY, G. A. (1977). Classification of plasmids in Pseudomonas aeruginosa. In Microbiology, pp. 119-126. Edited by D. Schlessinger. Washington, DC: American Society for Microbiology.

KEEN, N. T. (1990). Gene-for-gene complementarity in plant-pathogen interactions. Annual Review of Genetics 24, 447-463.

KInG, E. O., Ward, M. K. \& Raney, D. E. (1954). Two simple media for the demonstration of pyocyanin and fluorescein. Journal of Laboratory and Clinical Medicine 44, 301-307.

Lawrence, G. J., Mayo, G. M. E. \& Shepherd, K. W. (1981). Interactions between genes controlling pathogenicity in the flax rust fungus. Phytopathology 71, 12-19.

Loper, J. E., Orser, C. S., Panopoulos, N. J. \& Schroth, M. N. (1984). Genetic analysis of fluorescent pigment production in Pseudomonas syringae pv. syringae. Journal of General Microbiology 130, 1507-1515.

MALIK, A. N. (1985). Genetic studies with Pseudomonas syringae pathovar pisi. $\mathrm{PhD}$ thesis, CNAA, Thames Polytechnic.
Malik, A. N., Vivian, A. \& TAYLOR, J. D. (1987). Isolation and partial characterization of three classes of mutant in Pseudomonas syringae pathovar pisi with altered behaviour towards their host, Pisum sativum. Journal of General Microbiology 133, 2393-2399.

Michelmore, R. W., Norwood, J. M., Ingram, D. S., Crute, I. R. \& Nicholson, P. (1984). The inheritance of virulence in Bremia lactucae to match resistance factors $3,4,5,6,8,9,10$ and 11 in lettuce (Lactuca sativa). Plant Pathology 33, 301-315.

Murray, N. E., Brammar, W. J. \& Murray, K. (1977). Lambdoid phages that simplify the recovery of in vitro recombinants. Molecular and General Genetics 150, 53-61.

NoRwoOd, J. M. \& CRUTE, I. R. (1984). The genetic control and expression of specificity in Bremia lactucae (lettuce downy mildew). Plant Pathology 33, 385-400.

SAMBORSKI, D. J. \& DYCK, P. L. (1968). Inheritance of virulence in wheat leaf rust on the standard differential wheat varieties. Canadian Journal of Genetics and Cytology 10, 24-32.

SambrooK, J., Fritsch, E. F. \& Maniatis, T. (1989). Molecular Cloning: a Laboratory Manual, 2nd edn. Cold Spring Harbor, NY: Cold Spring Harbor Laboratory.

Staskawicz, B. J., Dahlbeck, D. \& Keen, N. T. (1984). Cloned avirulence gene of Pseudomonas syringae pv. glycinea determines race-specific incompatibility on Glycine max (L) Merr. Proceedings of the National Academy of Sciences of the United States of America 81, 6024-6028.

Staskawicz, B., Dahlbeck, D., Keen, N. \& Napoli, C. (1987). Molecular characterization of cloned avirulence genes from race 0 and race 1 of Pseudomonas syringae pv. glycinea. Journal of Bacteriology 169, 5789-5794.

Taylor, J. D., Bevan, J. R., Crute, I. R. \& Reader, S. L. (1989). Genetic relationship between races of Pseudomonas syringae pathovar pisi and cultivars of Pisum sativum. Plant Pathology 38, 364-375.

Threlfall, E. J., Rowe, B., Ferguson, J. L. \& Ward, L. R. (1986). Characterization of plasmids conferring resistance to gentamicin and apramycin in strains of Salmonella typhimurium phage type 204c isolated in Britain. Journal of Hygiene 97, 419-426.

Vivian, A. (1992). Avirulence genes in Pseudomonas syringae pathovars. In Pseudomonas Molecular Biology and Biotechnology, pp. 37-42. Edited by E. Galli, S. Silver \& B. Witholt. Washington DC; American Society for Microbiology.

Vivian, A., Errington, J. \& Veal, D. (1983). The genetics of the cherry pathogen, Pseudomonas syringae pathovar morsprunorum. In Molecular Genetics of the Bacteria-Plant Interaction, pp. 333-339. Edited by A. Pühler. Berlin, Heidelberg: Springer-Verlag.

Vivian, A., Atherton, G. T., Bevan, J. R., Crute, I. R., Mur, L. A. J. \& TAYLOR, J. D. (1989). Isolation and characterization of cloned DNA conferring specific avirulence in Pseudomonas syringae pv. pisi to pea (Pisum sativum) cultivars, which possess the resistance allele, R2. Physiological and Molecular Plant Pathology 34, 335-344.

Watanabe, T., Furuse, C. \& Sakaizumi, S. (1968). Transduction of various R factors by phage P1 in Escherichia coli and by phage P22 in Salmonella typhimurium. Journal of Bacteriology 96, 1791-1795.

Whalen, M. C., Stall, R. E. \& Staskawicz, B. J. (1988). Characterization of a gene from a tomato pathogen determining hypersensitive resistance in non-host species and genetic analysis of this resistance in bean. Proceedings of the National Academy of Sciences of the United States of America 85, 6743-6747.

Whalen, M. C., InNes, R. W., Bent, A. F. \& Staskawicz, B. J. (1991). Identification of Pseudomonas syringae pathogens of Arabidopsis and a bacterial locus determining avirulence on both Arabidopsis and soybean. The Plant Cell 3, 49-59.

WILSON, G. G. \& MURRAY, N. E. (1991). Restriction and modification systems. Annual Review of Genetics 25, 585-627. 